\title{
Effects of Iron Oxide Nano-Particles on the Intestinal Tissue of Common Carp, Cyprinus Carpio
}

\section{Shila Omidzahir*1(D), Maliheh Alijantabar Bayi 1(D), Fatemeh Kardel 2(D), Mohammad Mazandarani 3 ic}

1. Department of Marine and Oceanic Sciences, University of Mazandaran. Babolsar, Iran.

2. Department of Environmental Sciences, University of Mazandaran. Babolsar, Iran.

3. Department of Fisheries and Environmental Sciences, Gorgan University of Agricultural Sciences and Natural Resources. Gorgan, Iran.

Article Info A B S T R A C T

Article Type:

Original Research

\section{Article History:}

Received: 20.05.2019

Accepted: 01.07.2019

*Corresponding Author:
Shila Omidzahir
Department of Marine and Oceanic
Sciences, University of Mazandaran.
Babolsar, Iran.
E-mail:sh.omidzahir@umz.ac.ir

Department of Marine and Oceanic

Babolsar, Iran.

E-mail:sh.omidzahir@umz.ac.ir

\section{Background:}

The application of nano-particles (NPs) in various industries is growing. Since their toxicity is not clearly understood, they can cause adverse effects on the environment. The aim of this study was to evaluate the histopathological effects of iron oxide nano-particles on the small intestine of common carp, Cyprinus carpio.

Methods:

Four experimental treatments were designed (15 fish/treatment). Treatment 1 was the controls while Treatments 2,3 and 4 were experimental. The experimental groups were exposed to 50,75 and the $100 \mathrm{mg} / \mathrm{L}$ of iron oxide NPs, respectively. On days 14, 21 and 28, the fish were randomly picked from each tank, samples of the small intestine were dissected, and were examined for both the accumulation of the iron NPs and the tissue histopathologies.

Results:

The highest concentration of iron accumulation was detected for Treatment 3 on day 21 , compared to all other treatment groups $(\mathrm{p}<0.05)$. However, iron accumulation in the tissue declined unexpectedly after day 21 despite the continued treatments at $100 \mathrm{mg} / \mathrm{L}$ of the iron NPs. The histopathological examinations revealed that the treatment beyond 21 days caused damages to the intestinal epithelial cells, including enterocytes, villi and the goblet cells.

Conclusion:

This study demonstrated that the effect of iron oxide NPs on the small intestinal tissue was dependant on the dose and duration of exposure. We conclude that the iron accumulation in the small intestine declined despite increasing the iron oxide NPs concentration and the exposure duration secondary to damages caused to the intestinal epithelial cell layer.

Keywords:

Bioaccumulation, Cyprinus Carpio, Histopathology, Intestinal Epithelia, Iron Oxide Nanoparticles.

How to cite this paper

Omidzahir S, Alijantabar Bayi M, Kardel F, Mazandarani M. Effects of iron oxide nano-particles on the intestinal tissue of Common carp, Cyprinus carpio. Iran J Toxicol.2019; 13 (3): 33-38

\section{INTRODUCTION}

Nanotechnology is the study of particles sized between 1 to 100 nanometers, the production and application of which are growing rapidly worldwide (1). Metal NPs are often made of one metal, metal oxides or a combination of different metals $(\underline{2,3})$. Increasing production of nano-particles and its application in different industries have caused potential risks in the environment, particularly in aquatic ecosystems where deposition and accumulation of the nano-particles occur (므). Metal NPs are absorbed easily by various organisms via food and water. Consequently, the interaction of NPs with organisms may result in physiological and biochemical abnormalities ( $\underline{4}$ ). Characteristics of NPs are different and some recent studies suggest that they may have negative effects on the aquatic environment ( $\underline{5})$.

Iron oxide NPs is one of the metal species, widely used in different industries and sciences, according to its magnetic properties, catalytic properties and its ability to pollute the environment $(\underline{1,6})$. However,

significant growth and application of iron oxide NPs brings about risks and concerns ( $\underline{2}$ ). Although iron is essential for life in all vertebrates and plays a vital role in bodily functions, such as respiratory chain reactions, oxygen transport and immune system (ㅁ), if its concentration exceeds a safe and optimal level it causes harmful effects in organisms (ㅁ) $)$ Abnormalities such as slow motion, visual impairment and increase in mortality in Oryzias latipes (ㅁ) $)$ physiological changes such as increased levels of hemoglobin, red blood cells, 
hematocrit and decrease in white blood cells in Indian carp, Labeo rohita, were reported following exposure to iron oxide nano-particles (4).

The widespread applications of iron oxide NPs require more comprehensive studies (ㄹ). However, limited studies have been conducted on the effects of iron oxide nano-particles in fish so far $(\underline{5,9})$. The purpose of this study was to evaluate the bioaccumulation and histopathology of iron oxide NPs in the small intestinal tissues of $C$. carpio, as the target organ for the uptake of iron.

\section{MATERIALS AND METHODS}

Experimental Set-up: In this study, 60 juvenile $C$. carpio fish with an average weight of $57.81 \pm 10.20 \mathrm{~g}$ and length of $14.69 \pm 0.91 \mathrm{~cm}$ were caught from a fish pond. After one week of adaptation in the laboratory, the fish were put in four separate tanks of 30L capacity each (15 fish/tank). Fish were maintained at $25 \pm 1^{\circ} \mathrm{C}$ with the water continuously aerated, the oxygen at 6.5 $\mathrm{mg} / \mathrm{L}, \mathrm{pH} 7.2-7.4$, and the hardness set at 185-200 $\mathrm{mg} / \mathrm{L}$. The water in each tank was renewed every second day and the right amount of iron oxide NPs was added. The laboratory lighting was on a $12 \mathrm{~h}$ dark and $12 \mathrm{~h}$ light cycle.

The fish were divided into 4 treatment groups of 15 . Treatment-1 was the control and the other three experimental groups were designated as: Treatment-2, Treatment-3 and Treatment-4. The fish in the experimental groups were exposed to iron oxide NPs dissolved in tap water at 50, 75 and $100 \mathrm{mg} / \mathrm{L}$, respectively. The experiments were conducted for a period of 28 days and the sampling occurred on days 14, 21 and 28 post exposure to the iron oxide NPs. For this purpose, five fish were taken out randomly, anesthetized with clove oil and euthanized for further analysis. All ethical considerations regarding experimental animals were observed for the fish during the conduction of the experiments. All experimental processes and tests were performed in triplicates.

Iron Oxide NPs Preparation: The solutions of iron oxide NPs were made from the powder (US Research Nano-materials Inc, USA; Figure 1) suspended in distilled water, using a bath type sonicator (Elma $\mathrm{E} 30 \mathrm{H}$, Germany). The appropriate concentration of iron oxide NPs suspension was added to the water in each tank, with the aeration pump running constantly to mix water and prevent or minimize the particles from settling ( $\underline{4})$.
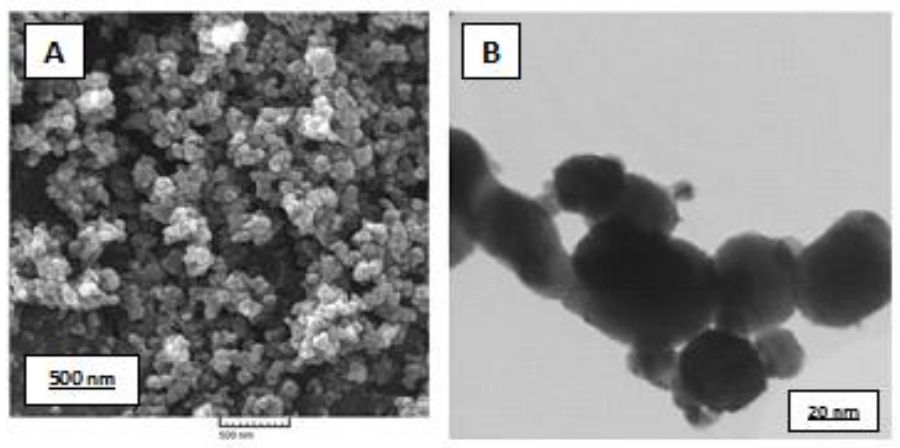

Figure 1. Morphological images of $\mathrm{Fe}_{2} \mathrm{O}_{3}$ NPs used in the present study. A: Scanning electron microscopic image; B: Transmission electron microscopic image.
Bioaccumulation Analysis: A $1.5 \mathrm{~cm}$ sample of the small intestine was dissected from each fish and dried in the oven for 96 hours. The dried tissue samples were pulverized to powder separately in a porcelain mortar. For chemical digestion, $5 \mathrm{ml}$ of nitric acid 69\% (Merck, Germany) and $2 \mathrm{ml}$ of perchloric acid 60\% (Merck, Germany) were added to $0.5 \mathrm{~g}$ of dried powdered samples, and poured into polyethylene tubes. The samples remained at room temperature overnight, and then placed in a water bath at $100^{\circ} \mathrm{C}$ for two hours. After completing the digestion process, the suspensions were passed through paper filter, and the volume increased to $25 \mathrm{ml}$ by $1 \%$ nitric acid (10). The small intestinal samples were analyzed for their iron concentrations with an atomic absorption spectrophotometer (AAS; Analytic jenaAA-400; Germany). The following formula was used to calculate the actual iron concentration (10):

The concentration of iron in the samples $(\mu \mathrm{g} / \mathrm{g})=$ AAS reading of the digest $(\mu \mathrm{g} / \mathrm{ml}) \times$ volume of the digested solution used (ml) / weight of the samples digested (g).

Histopathological Analysis: Tissue samples (1.5 $\mathrm{cm}$, each fish) of the small intestines were dissected for each of the four treatments, and fixed in 10\% formalin buffer. They were prepared in a tissue processor (DID SABZ-2080/H, Iran). Serial sections of formalin-fixed, paraffin-embedded samples were made, using rotary microtome at $5 \mu \mathrm{m}$ (Leitz 1512, Germany). Sections were stained with Hematoxylin and Eosin (H\&E) for histopathological examinations (11). Also, ALB and PAS staining were performed for goblet cells quantification for the various treatments. Goblet cells were counted in ten microscopic fields (magnification x 40) for each treatment group (11). These samples were examined under light microscopy (Olympus CX21, Japan) equipped with a digital camera (Tucsen True Chrome Metrics, China). The histopathology samples were graded as "no change, mild, moderate, or severe lesions $(-,+,++\&+++)$, respectively. The length and width of the intestinal villi were measured for each treatment under light microscopy at magnification $\mathrm{x} 40$ (12).

Statistical Analysis: The normality of the data evaluated using Kolmogorov-Smirnov test. One-way analysis of variance (ANOVA) and Duncan's test for multiple comparisons was performed for the analysis of significant differences in iron concentrations, number of goblet cells and the length and width of intestinal villi from different treatments. Statistical analysis was done using software SPSS, version 22 .

\section{RESULTS}

\section{Bioaccumulation of Iron in the Intestinal}

Tissue: In the present study, the highest concentrations of iron nano-particles were observed in samples from treatment 3 on day 21 , which were significantly different compared to the results for other treatments $(\mathrm{p}<0.05)$. In treatment 2 , the iron concentration increased over exposure time, with the highest concentrations observed for day 28, which were significantly different compared to those for day 
$14(\mathrm{p}<0.05)$. In treatment 3 , the highest concentrations were seen for day 21 , which were significantly different compared to those for days 14 and $28(\mathrm{p}<0.05)$. In treatment 4, iron concentrations decreased over exposure time, with the lowest concentrations observed for day 28. However, there were no significant differences among the treatment samples ( $p>0.05$; Figure 2).

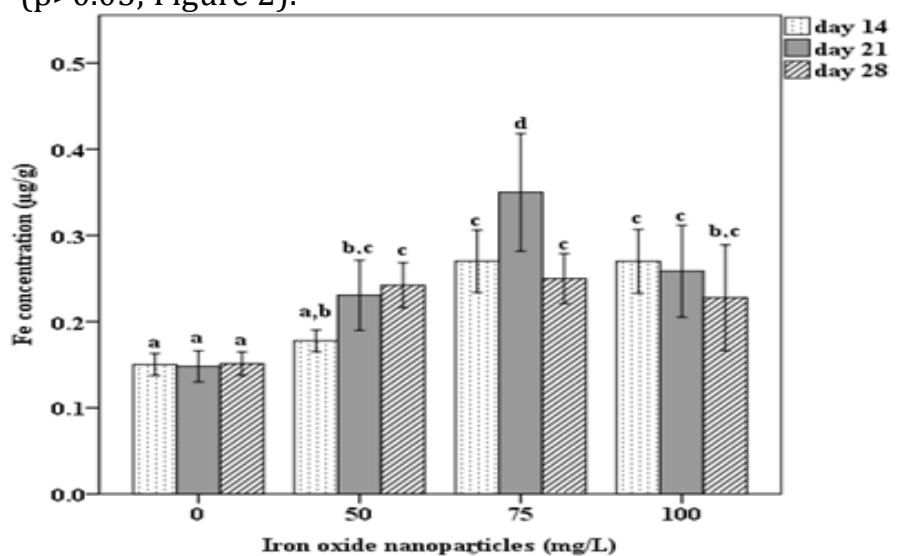

Figure 2. Iron oxide NPs concentrations (mean \pm SE) detected in different treatments. The superscript letters above the bar graphs in alphabetical order "a, b, c \& d" were obtained according to the multiple comparisons on Duncan's test and different letters indicate levels of significant difference $(\mathrm{p}<0.05)$ among various treatments, while similar letters indicate no significant difference $(p>0.05)$.

\section{Histopathological Findings in Intestinal}

Tissues: In the control group, normal histological structures were observed. In treatment 2, mild infiltration of inflammatory cells and epithelial cell destructions were noted for days 21 and 28. Similarly in treatment 3 , mild infiltration of inflammatory cells and epithelial cell destructions were also observed on days 14,21 . Moderate infiltration of inflammatory cells and epithelial cell destructions were seen on day 28. In treatment 4 , sever infiltration of inflammatory cells and epithelial destructions were observed in the tissue samples. See Table 1 and Figure 3.

Table 1. Histopathological lesions observed in the different treatments.

\begin{tabular}{cccccc}
\hline \multirow{2}{*}{ Cellular Lesion } & $\begin{array}{c}\text { Exposure } \\
\text { (day) }\end{array}$ & \multicolumn{4}{c}{ Iron Oxide NPs (mg/L) } \\
\cline { 3 - 6 } & 14 & $\mathbf{0}$ & $\mathbf{5 0}$ & $\mathbf{7 5}$ & $\mathbf{1 0 0}$ \\
\hline \multirow{2}{*}{ inflammatory Cell } & 21 & - & - & + & +++ \\
Infiltration & 28 & - & + & + & +++ \\
\multirow{2}{*}{ Epithelial } & 14 & - & - & ++ & +++ \\
Destruction & 21 & - & + & + & +++ \\
& 28 & - & + & ++ & +++ \\
\hline
\end{tabular}

Key: -, +, ++ and +++ indicate no change, mild, moderate, and severe lesions, respectively.
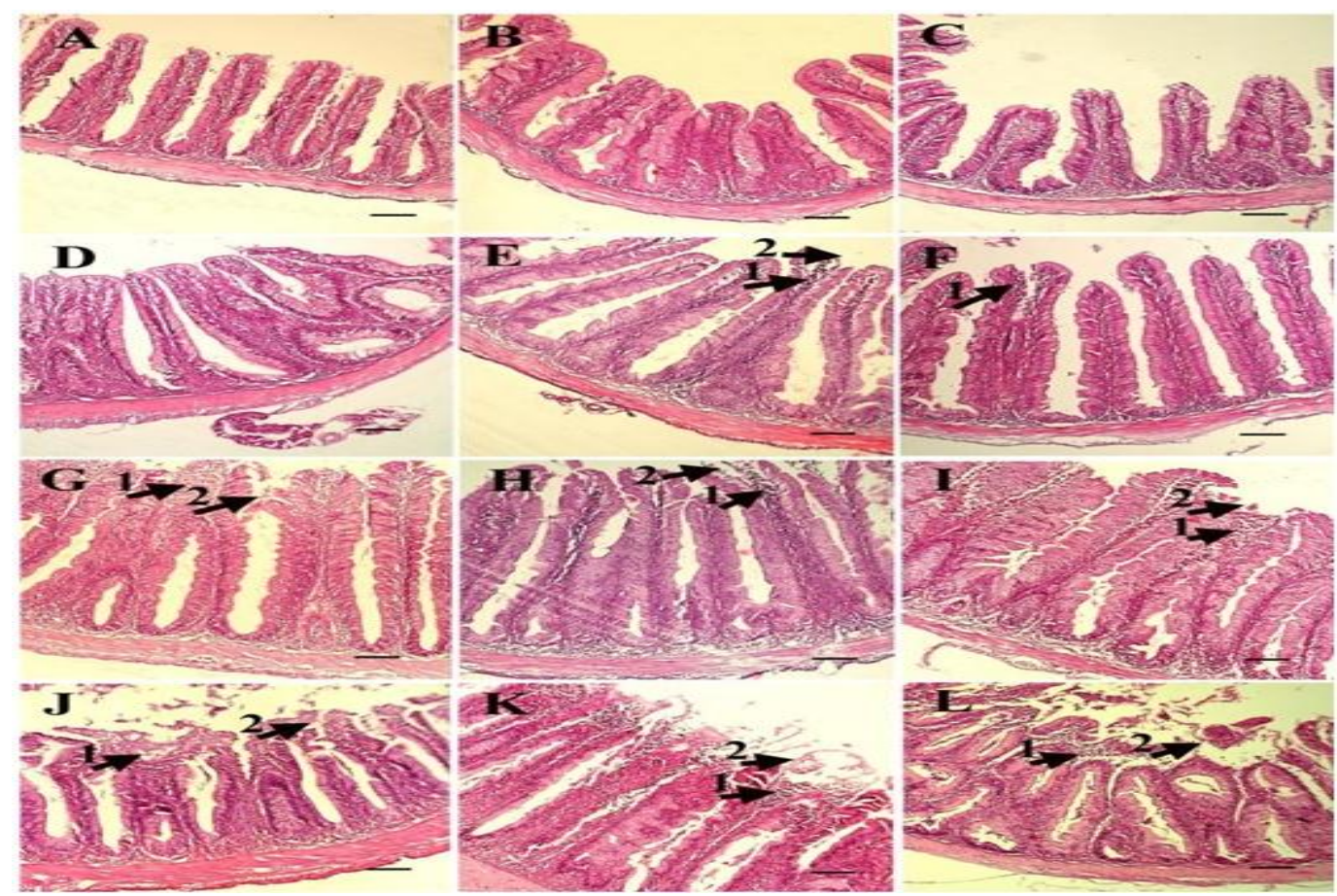

Figure 3. A, B and C: Treatment 1 on days 14,21 and 28. D, E and F: Treatments 2 on days 14, 21 and 28 . G, H \& I: Treatments 3 in days 14,21 and 28. J, K and L: Treatments 4 in days 14, 21 and 28. A, B and C show normal conditions. In other treatments, arrows 1 denote infiltration of inflammatory cells and arrows 2 show epithelial cells destruction. H \& E staining; Bars in micrographs $=100 \mu \mathrm{m}$.

Width and Length of Intestinal Villi: In Treatment 1 , the width and length of the intestinal villi revealed no significant differences on days 14, 21 and 28 of the exposure to the NPs $(p>0.05)$. In Treatment 2 , the width and length of villi increased over exposure time, with the most significant increases observed on day 28 $(\mathrm{p}<0.05)$. In Treatment 3 , the width and length of villi increased progressively up to day $21 \quad(\mathrm{p}<0.05)$. However, these dimensions decreased on day 28. In treatment 4, a progressively decreasing trend was observed in the width and length of the villi, with the maximum decrease observed on day 28 (Table 2).

Intestinal Goblet Cells: As shown in Table 3, the overall pattern of change in the goblet cell numbers in response to exposure to iron oxide nano-particles was similar. The ALB staining (Fig. 4) appeared to identify the goblet cells more readily than the PAS staining (Fig. $5)$. 


\begin{tabular}{cccccc}
\multicolumn{6}{c}{ Table 2. Measurement of length and width of intestinal villi. } \\
\hline Villi $(\boldsymbol{\mu m})$ & $\begin{array}{c}\text { Exposure } \\
\text { (day) }\end{array}$ & $\mathbf{0}$ & $\mathbf{5 0}$ & $\mathbf{5 0}$ & $\mathbf{1 0 0}$ \\
\hline \multirow{3}{*}{ Width } & 14 & $79.9 \pm 2.56^{\mathrm{a}}$ & $102.9 \pm 2.51^{\mathrm{b}}$ & $121.8 \pm 1.38^{\mathrm{d}}$ & $118.7 \pm 2.9^{\mathrm{c}, \mathrm{d}}$ \\
& 21 & $80.8 \pm 2.11^{\mathrm{a}}$ & $123.7 \pm 4.27^{\mathrm{d}, \mathrm{e}}$ & $139.7 \pm 2.88^{\mathrm{f}}$ & $114.5 \pm 3.21^{\mathrm{c}, \mathrm{d}}$ \\
& 28 & $81 \pm 1.88^{\mathrm{a}}$ & $132.3 \pm 2.07^{\mathrm{f}}$ & $134.9 \pm 3.06^{\mathrm{e}, \mathrm{f}}$ & $109.7 \pm 5.78^{\mathrm{b}, \mathrm{c}}$ \\
& 14 & $426.2 \pm 6.62^{\mathrm{a}}$ & $591.1 \pm 13.28^{\mathrm{c}}$ & $601.4 \pm 4.87^{\mathrm{c}, \mathrm{d}}$ & $594.3 \pm 10.78^{\mathrm{c}, \mathrm{d}}$ \\
Length & 21 & $435.9 \pm 7.4^{\mathrm{a}}$ & $603.8 \pm 6.1^{\mathrm{c}, \mathrm{d}, \mathrm{e}}$ & $626.8 \pm 7.76^{\mathrm{f}}$ & $551.6 \pm 11.71^{\mathrm{b}}$ \\
& 28 & $439.2 \pm 7.26^{\mathrm{a}}$ & $618.7 \pm 4.65^{\mathrm{e}, \mathrm{f}}$ & $611.4 \pm 5.18^{\mathrm{c}, \mathrm{d}, \mathrm{e}}$ & $538.1 \pm 3.6^{\mathrm{b}}$ \\
\hline
\end{tabular}

Values are means \pm SE for different treatments. The superscript letters in alphabetical order "a, b, c, d, e \& f” were obtained according to the multiple comparisons on Duncan's test. Different superscript letters indicate levels of significant difference $(p<0.05)$ among the treatments, while similar letters indicate no significant difference $(\mathrm{p}>0.05)$.

Table 3. Number of goblet cell stained with ALB or PAS in different treatments.

\begin{tabular}{cccccc}
\hline Staining & $\begin{array}{c}\text { Exposure } \\
\text { (day) }\end{array}$ & $\mathbf{0}$ & $\mathbf{5 0}$ & $\mathbf{7 5}$ & $\mathbf{1 0 0}$ \\
\cline { 3 - 6 } & 14 & $24.3 \pm 0.81^{\mathrm{a}}$ & $28.2 \pm 0.89^{\mathrm{b}}$ & $35.9 \pm 0.75^{\mathrm{d}}$ & $33.9 \pm 0.99^{\mathrm{c}, \mathrm{d}}$ \\
\multirow{3}{*}{$\mathrm{ALB}$} & 21 & $25 \pm 0.55^{\mathrm{a}}$ & $33 \pm 1.19^{\mathrm{c}}$ & $40.1 \pm 1.13^{\mathrm{e}}$ & $31.8 \pm 0.68^{\mathrm{c}}$ \\
& 28 & $25.2 \pm 0.62^{\mathrm{a}}$ & $32.1 \pm 1.01^{\mathrm{c}}$ & $38.9 \pm 1.39^{\mathrm{e}}$ & $28.7 \pm 1.26^{\mathrm{b}}$ \\
& 14 & $17.1 \pm 0.56^{\mathrm{a}}$ & $22.4 \pm 0.89^{\mathrm{b}, \mathrm{c}}$ & $26.1 \pm 0.72^{\mathrm{d}, \mathrm{e}}$ & $25.7 \pm 0.96^{\mathrm{d}, \mathrm{e}}$ \\
\multirow{3}{*}{ PAS } & 21 & $18.3 \pm 0.71^{\mathrm{a}}$ & $24.3 \pm 0.97^{\mathrm{b}, \mathrm{c}}$ & $31.5 \pm 1.32^{\mathrm{g}}$ & $24.7 \pm 1.36^{\mathrm{c}, \mathrm{d}, \mathrm{e}}$ \\
& 28 & $18.8 \pm 0.41^{\mathrm{a}}$ & $27.3 \pm 0.76^{\mathrm{e}, \mathrm{f}}$ & $29.8 \pm 0.99^{\mathrm{f}, \mathrm{g}}$ & $21.8 \pm 0.94^{\mathrm{b}}$ \\
\hline
\end{tabular}

Values are means $\pm \mathrm{SE}$ for different treatments. The superscript letters in alphabetical order "a, b, c, d, e \& f" were obtained according to the multiple comparisons on Duncan's test. Different superscript letters indicate levels of significant difference $(p<0.05)$ among the treatments, while similar letters indicate no significant difference $(\mathrm{p}>0.05)$.
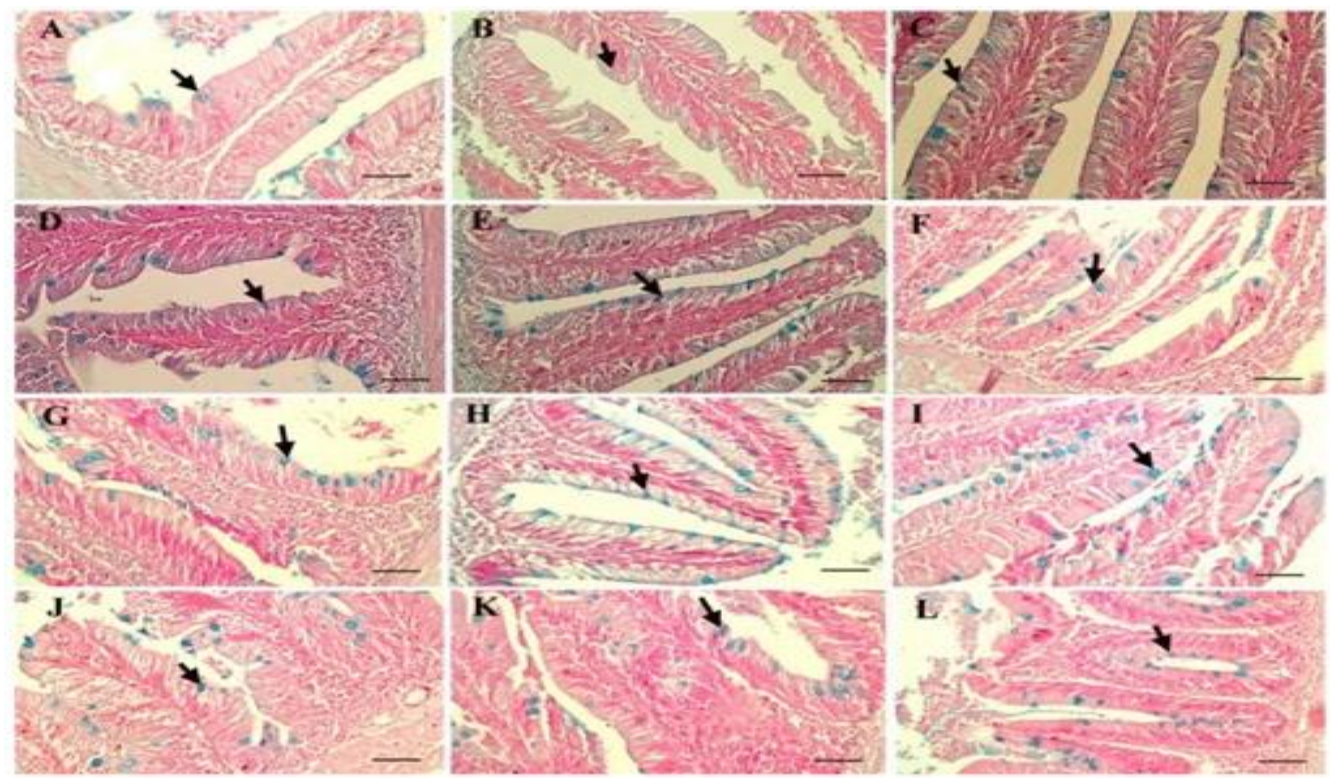

Figure 4. A, B and C: Treatments 1 in days 14, 21 and 28. D, E and F: Treatments 2 in days 14, 21 and 28. G, H and I: Treatments 3 in days 14, 21 and 28. J, K and L: Treatments 4 in days 14, 21 and 28. The arrow in each panel represents a sample of goblet cells. ALB staining; Bars in micrographs = $50 \mu \mathrm{m}$.

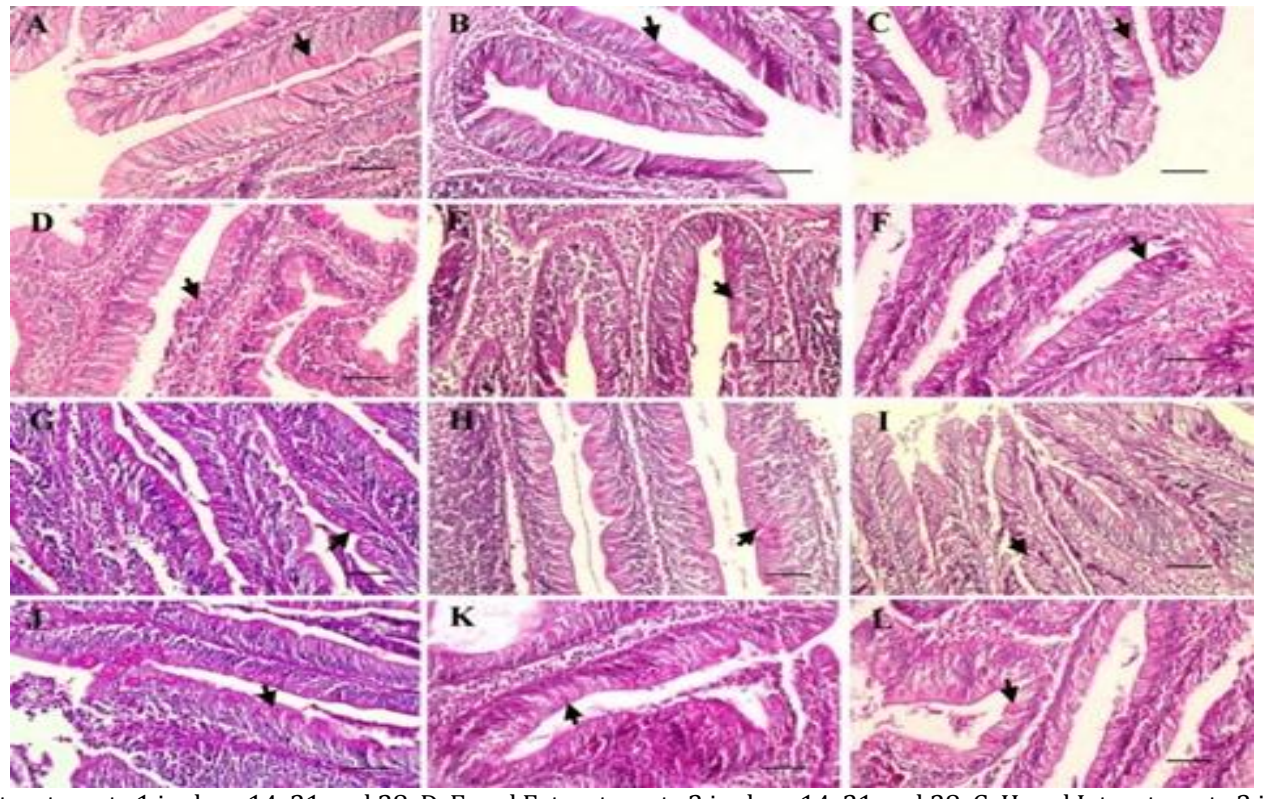

Figure 5. A, B and C: treatments 1 in days 14, 21 and 28. D, E and F: treatments 2 in days 14, 21 and 28. G, H and I: treatments 3 in days 14, 21 and 28. J, K and L: treatments 4 in days 14, 21 and 28. The arrow in each panel represents a sample of goblet cells. PAS staining; Bars in micrographs $=50 \mu \mathrm{m}$. 
In Treatment 1, there was an insignificant increase ( $>0.05$ ) in goblet cell numbers as the days progressed to day 28 , in both staining groups (Figures $4 \& 5$ ).

In Treatment 2, the number of goblets cells for ALB stained samples increased significantly compared to that for day $14(\mathrm{p}<0.05)$, with the peak occurring on day 21 (Fig. 4). However, the number of goblets cells for PAS stained samples increased up to day 28, that was significant compared to those for day 14 and 21 ( $\mathrm{p}<0.05$; Fig. 5).

In Treatment 3, the exposure to the NPs appeared to cause the most significant increases for day of 21 $(p<0.05)$ in goblet cell numbers across the experimental groups in both ALB and PAS stained samples, except for day 28 ( $p>0.05)$.

In Treatment 4, there was a significant decrease in the goblet cell numbers as the exposure to the NPs progressed to day $28(\mathrm{p}<0.05)$.

\section{DISCUSSION}

The aim of this study was to evaluate the bioaccumulation and histopathology effects of iron oxide NPs on the intestinal tissues as the target organ for the uptake of iron in C. carpio fish. The intestinal epithelia covered with mucous layer is the first entry gate for the ingested iron (13).The mucus protects the intestinal epithelia from damage and infection, and helps the digestion and absorption processes. Goblet cells secrete mucin that has an important role in the absorption of iron (14). Iron ions bound to mucin passes through the mucous layer $(\underline{15})$ and enters the enterocytes via the divalent metal transporter. Subsequently, iron ions leave the enterocytes with ferroportin and enter the circulatory system bound to transferrin, distribute and eventually play vital roles in various bodily organs (16).

The accumulation of heavy metals in various organs depends on their physiological roles $(\underline{17,18})$. The capacity of metallothioneins (the proteins that bind to heavy metals) in various organs is the basis for differences in their accumulation (19). The interactions between nano-particles and certain living organisms have recently been studied (20) $)$. Nevertheless, the mechanism of action in their body is not clearly understood. The intestinal enterocytes are the primary target cells to transfer NPs into the body, and their villi promote the absorption of such materials. The cellular processes of NPs transfer into enterocytes include endocytosis, intracellular transport and exocytosis (20).

The present study demonstrated that the bioaccumulation of iron oxide NPs in C. carpio's intestinal tissue increased up to day 21 of exposure (treatment 3), as evidenced by an increase in the number of goblet cells, and the length and width of intestinal villi. However, there was an unexpected decline in the iron concentration in the tissue after day 21. Further histopathological examinations of the intestinal tissue revealed that the exposure to the NPs eventually damaged the epithelial cells including enterocytes, villi and goblet cells. These observations suggest that the intestinal cells lost their ability to continue to accumulate iron particles. Further, the findings of this study are consistent with those reported by previous researchers on the undesirable effects of the NPs on the integrity of the small intestine in $C$. carpio. The major destructive effects of the NPs were degeneration and reduction in the number of intestinal villi, thinning of the intestinal wall, epithelial cell swelling, and loss of the cell junctions $(\underline{2,6})$.

\section{CONCLUSION}

This study provided experimental evidence on the effect of iron oxide NPs on intestinal tissue, which was dose and duration dependent. Histopathological examinations of the exposed tissue and the bioaccumulation analyses of the NPs revealed that intestinal tissue was damaged and lost normal ability to accumulate iron after day 21 of exposure. It can be concluded that the NPs accumulation was reduced in the intestinal tissue despite an increase in the concentration and exposure duration due to intestinal tissue damages caused by the NPs. Thus, the monitoring of released iron NPs to the aquatic environment is essential for the health and management of ecosystem.

\section{ACKNOWLEDGEMENT}

This article was extracted from the M.Sc. thesis project, conducted by Ms. Maliheh Alijantabar Bayi.

The authors would like to thank Dr. Seyyed Mohammad Hosseini, Veterinary Pathologist, Islamic Azad University, Babol Campus, Babol, Iran. We also appreciate Ms. Zohreh Shahzade Aliakbari and Ms. Roghayeh Khoda Bandeloo for their valuable assistance with this study.

\section{CONFLICT OF INTEREST}

The authors declare no conflicting interest with any entity in the course of conducting this study.

\section{REFERENCES}

1. Zhu X, Tian S, Cai Z. Toxicity assessment of iron oxide nanoparticles in zebrafish (Danio rerio) early life stages. PLoS One. 2012;7(9):e46286. doi.org/10.1371/journal.pone.0046286.

2. Li $\mathrm{H}, \mathrm{Zhou} \mathrm{Q}, \mathrm{Wu} \mathrm{Y,Fu} \mathrm{J,} \mathrm{et} \mathrm{al.} \mathrm{Effects} \mathrm{of} \mathrm{waterborne}$ nano-iron on medaka (Oryzias latipes): antioxidant enzymatic activity, lipid peroxidation and histopathology. Ecotoxicology and environmental safety, 2009;72(3):684-692. 10.1016/j.ecoenv.2008.09.027.

3. Shaw BJ, Handy RD. Physiological effects of nanoparticles on fish: a comparison of nanometals versus metal ions. Environment International. 2011;37(6):1083-97.

4. Remya AS, Ramesh M, Saravanan M, et al. Iron oxide nanoparticles to an Indian major carp, Labeo rohita: impacts on hematology, iono regulation and gill $\mathrm{Na}^{+} / \mathrm{K}^{+}$ ATPase activity. J King Saud Univ Sci. 2015;27(2):151-60.

5. Saravanan M, Suganya R, Ramesh $M$, et al. Iron oxide nanoparticles induced alterations in haematological, biochemical and ionoregulatory responses of an Indian 
major carp Labeo rohita. J Nanopart Res. 2015;17(6):274. Doi: 10.1007/s11051-015-3082-6

6. Chen PJ, Wu WL, Wu KCW. The zero valent iron nanoparticle causes higher developmental toxicity than its oxidation products in early life stages of medaka fish. Water Res. 2013;47(12):3899-909.

7. Wood CM, Farrell AP, Brauner CJ. Fish Physiology: Homeostasis and Toxicology of Essential metals. Canada, Academic press. 2012. ISBN: 9780123786364

8. Van der Oost R, Beyer J, Vermeulen NP. Fish bioaccumulation and biomarkers in environmental risk assessment: A review. Environ Toxicol Pharm. 2003;13(2):57-149.

9. Karthikeyeni S, Siva Vijayakumar T, Vasanth S, et al. Biosynthesis of iron oxide nanoparticles and its haematological effects on fresh water fish Oreochromis mossambicus. J Acad Indus Res. 2013;10:645-9.

10. Al-Weher SM. Levels of heavy metal $\mathrm{Cd}, \mathrm{Cu}$ and $\mathrm{Zn}$ in three fish species collected from the northern Jordan valley, Jordan. Jordan J Biol Sci. 2008;1(1):41-6.

11. Bancroft JD, Gamble M. Theory and practice of histological techniques. Elsevier Health Sciences. 2008.

12. Thophon S, Kruatrachue $\mathrm{M}$, Upatham ES, et al. Histopathological alterations of white seabass, Lates calcarifer, in acute and subchronic cadmium exposure. J Environ Poll. 2003;121:307-20.

13. Bury NR, Grosell M. Waterborne iron acquisition by a freshwater teleost fish, zebrafishDaniorerio. J Exp Biol. 2003; 206(19):3529-35.
14. Bury NR, Grosell M, Wood CM, et al. Intestinal iron uptake in the European flounder (Platichthys flesus). J Exp Biol. 2001;204(21):3779-87.

15. Cooper CA, Shayeghi M, Techau ME, et al. Analysis of the rainbow trout solute carrier 11 family reveals iron import $\leqslant \mathrm{pH} 7.4$ and a functional isoform lacking transmembrane domains 11 and 12. FEBS Lett. 2007;581(14):2599-604.

16. Carriquiriborde PR, Handy RD, Davies SJ. Physiological modulation of iron metabolism in rainbow trout (Oncorhynchus mykiss) fed low and high iron diets. Journal of Experimental Biology. 2004;207(1):7586.

17. Yilmaz AB. Levels of heavy metals $(\mathrm{Fe}, \mathrm{Cu}, \mathrm{Ni}, \mathrm{Cr}, \mathrm{Pb}$ and $\mathrm{Zn}$ ) in tissue of Mugil cephalus and Trachurus mediterraneus from Iskenderun Bay (Turkey). Journal of Environmental Rescerch. 2003;92:277-81.

18. Yilmaz AB. Comparison of heavy metal levels of Grey Mullet (Mugil cephalus L.) and Sea Bream (Sparus aurata L.) Caught in Iskenderun Bay (Turkey). Turkish Journal of Veterinary Animal Science. 2005;29:257-62.

19. Usero J, Izquierdo C, Morillo J, et al. Heavy metals in fish (Solea vulgaris, Anguilla anguilla and Liza aurata) from salt marshes on the southern Atlantic coast of Spain. Environment International. 2004;29(7):949-56.

20. Yu M, Yang Y, Zhu C, et al. Advances in the transepithelial transport of nanoparticles. Drug discovery today. 2016;21(7):1155-61. 